Published in Social Policy and Society (2015) in Volume 14, Issue 4: http://journals.cambridge.org/action/displayFulltext?type=1\&fid=9948058\&jid=SPS\&v olumeId=14\&issueId=04\&aid=9948053

\title{
Diminishing Returns: Lone Mothers' Financial Work Incentives and Incomes under the Coalition
}

Helen Kowalewska, University of Southampton, UK

\begin{abstract}
Lone mothers in the UK are a key target group of tax-benefit measures designed to "make work pay". This article assesses how the Conservative-Liberal Democrat Coalition's make work pay agenda since 2010 has potentially affected single mothers by calculating two lone mothers' incomes and incentives for a range of working hours and wage rates under the Coalition and previous New Labour government. It shows that while the Coalition's measures substantially improve the lone mothers' incentives to work in minijobs of fewer than 16 hours, their incentives to work longer are still weak if not weaker than under Labour. Furthermore, the financial returns to progressing in work begin to diminish once hours exceed just six at average wage and nine at minimum wage. While tougher conditionality may still push many lone parents to work longer, weak labour demand and reduced employment supports could undermine their abilities to meet increased work expectations.
\end{abstract}

Keywords: [make work pay; mini-jobs; New Labour; UK; Universal Credit] 


\section{Introduction}

Many reforms to the UK's tax-benefit system announced by the Conservative-Liberal Democrat Coalition from 2010 were underpinned by the aim of "making work pay". A key target group of these reforms were lone mothers, who currently head 23 per cent of all UK families with dependent children (ONS, 2015). This is partly because 41 per cent of lone mothers are not in paid employment compared to 33 per cent of lone fathers (ONS, 2011) and 28 per cent of mothers living with a partner (ONS, 2013). Furthermore, of those lone mothers who do work, 58 per cent are in low-paying sectors while 57 per cent work fewer than 30 hours a week (Harkness and Skipp, 2013). Lone parents also face some of the weakest incentives of all family types to start and progress in work. They not only tend to have low earnings potential, but are more likely than individuals in one- and two-earner couples and single people without children to receive generous out of work support and face the overlapping withdrawal of multiple means-tested benefits as earnings rise (Adam and Browne, 2010).

Lone mothers' employment behaviour is of course shaped by a range of factors, from culturally and socially situated ideas about "good" mothering (Duncan and Edwards, 1999) and "good enough" care for their children (Williams, 2004), to the availability of local jobs, childcare and transport (Rafferty and Wiggan, 2011). Nevertheless, research shows the perceived financial benefits and penalties of working created by the tax-benefit system can influence lone parents' employment decisions and be of overriding concern to many (Lister, 1999; Bell et al., 2005; Wiggan, 2005).

The article aims to illustrate financial work incentives and incomes for two hypothetical lone mothers under the Coalition government's reforms to direct taxes and cash benefits. It builds on recent studies which use micro-simulation models based on representative 
samples of actual lone parents to measure the likely impacts of the reforms on work incentives and incomes (for example, Browne, 2012; Adam and Browne, 2013; Adam and Phillips, 2013; De Agostini and Brewer, 2013; Reed et al., 2013; Brewer and De Agostini, 2015). In micro-simulation based studies, the impacts of the Coalition's reforms are shown to the extent they affect the lone parents contained in the relevant dataset. In contrast, hypothetical lone mothers can be assigned any set of characteristics; and by varying one characteristic at a time while holding all others constant, we are able to test whether the Coalition's reforms have the potential to deliver on its promise to make work pay for lone mothers under a range of different circumstances relevant to different groups of lone parents (Immervoll et al., 2004). In particular, the analysis illustrates how the hypothetical lone mothers' tax burdens and benefit entitlements vary with small increments in their labour supply. This can expose if there are certain "thresholds", in terms of working hours and/or earnings, from which the financial returns to increasing labour supply start to diminish as a result of the design of the Coalition's tax-benefit system (Berger et al., 2001).

While Brewer et al. (2012a, 2012b), Hirsch (2012), Pareliussen (2013) and Ghelani and Stidle (2014) have also examined the impacts of the Coalition's flagship make work pay reform, Universal Credit, on one or more hypothetical lone mother(s), this article extends such work in three main ways. First, it includes all changes to direct in work taxes and cash benefits announced by the Coalition in addition to Universal Credit, including important changes to support for Council Tax and income tax. Second, it compares the hypothetical lone mothers' incentives under the Coalition's reform package with the incentives they could have expected if the previous Labour government's tax-benefit system had instead continued, with amounts adjusted for inflation. Third, the article situates the findings within their broader context. It describes the policy context by 
comparing welfare-to-work reforms and the discourses behind them under Labour and the Coalition, and concludes by discussing what the findings might mean in practice for lone mothers given broader economic and policy changes.

The article shows that while the Coalition's make work pay agenda substantially improves the constructed lone mothers' financial incentives to work in mini-jobs of fewer than 16 hours a week, their incentives to work longer are weak and, in some cases, weaker than under Labour. In addition, total net incomes when working in 16 hour plus jobs are, for the most part, lower than under Labour. Moreover, the financial returns to progressing in work begin to diminish once hours exceed just six at average wage and nine at minimum wage, and virtually disappear for the lone mother with childcare costs when working hours fall outside of the school day.

The next section charts the development of lone parent welfare-to-work measures since 1997. The methods are reported in section three, followed by the results in section four. The article concludes by discussing the potential implications of the results for lone mothers within their broader context.

\section{Lone Parent Welfare-to-Work Reforms}

Whereas the previous Conservative government had been ambivalent towards lone mothers' participation in paid work (Lewis, 1998; Lister, 2002), governments since 1997 have made lone parents a key target group of welfare-to-work reform. This partly reflects an international trend towards activation policies designed to equip, encourage and compel lone parents to enter and progress in paid employment (Morel et al., 2012). It also reflects the influence of neo-liberal ideology and American-style workfarism (Slater, 2012), as well as consensus that 'work is good for you' (for example, DWP, 2007: 23; Freud, 2011) and a shared commitment to ending child poverty. Despite these continuities, 
there have been important shifts in the discourses underpinning and emphasis of lone parent welfare-to-work policies from the New Labour government to the Coalition.

\section{New Labour (1997-2010)}

As part of an agenda to modernize the Labour party by distancing it from the "tax-andredistribute" image of "Old" Labour governments, New Labour's welfare-to-work discourse suggested irresponsible attitudes and behaviours, exacerbated by dependency on state benefits, were partly to blame for worklessness (Driver and Martell, 1999; Deacon, 2003). Yet without abandoning social democratic principles altogether, its discourse emphasized worklessness was also a problem of inequality. It argued poor attitudes and behaviours among the workless were simply mechanisms for coping with the structural barriers they faced in accessing the same employment and education opportunities as other groups in society (Deacon, 2003).

In line with this discourse, New Labour sought, on the one hand, to increase employment supports in order to address some of the structural barriers lone parents faced in accessing employment opportunities. It introduced the New Deal for Lone Parents (subsumed into the Flexible New Deal in 2009), which offered personalized guidance and practical support in finding and sustaining work. It also implemented various measures to help lone parents balance work with caring responsibilities and improve the affordability and availability of childcare.

On the other hand, Labour's understanding of worklessness as partially rooted in behavioural factors underpinned a number of benefit reforms designed to influence and regulate lone parents' behaviour in favour of starting and progressing in work. Labour sought, in the first place, to encourage lone parent employment by making it pay. It introduced a National Minimum Wage and reduced in work taxes for low and average 
earners. However, its flagship make work pay reform was Working Families Tax Credit (replaced by the Working Tax Credit in 2003). This was available to lone parents working 16 hours or more a week, with a bonus at 30 hours. In contrast to the previous Conservative government's Family Credit, it was more generous, was withdrawn more slowly over a higher earnings threshold, and included a subsidy worth up to 80 per cent of childcare costs by the time Labour left office.

However, as the number of policy supports in place increased, Labour saw a progressive strengthening of the work-related conditions attached to lone parents' benefit receipt as increasingly necessary and justified for regulating their employment behaviour. This culminated with the introduction of Lone Parent Obligations in 2008. For the first time, lone parents were required to move from Income Support onto Jobseeker's Allowance and be available for work once their youngest child reached a certain age, which Labour intended to gradually reduce from 12 to seven years. There were however certain "flexibilities" for lone parents (Haux, 2012; Whitworth and Griggs, 2013). For instance, subject to a minimum availability requirement of 16 hours, lone parents with a child under 13 could restrict their work availability to normal school hours, while those with older children could restrict theirs according to their caring responsibilities. These flexibilities applied to all lone parents irrespective of the availability of local jobs at the required hours (see Kennedy, 2010 for an overview of all flexibilities).

Despite missed targets, Labour oversaw a rise in lone parent employment from 45 to 57 per cent (Haux, 2011; Waldfogel, 2011). While much of this was down to a strong economy and changes in the characteristics of both lone parents and the labour market (Gregg et al., 2006; Millar, 2010), evidence shows the first wave of reforms (1998-2003) alone led to a four to five percentage point increase in lone parent employment, with 
Working Families Tax Credit the main driver behind this gain. In particular, the reforms improved job retention during the initial transition into lone parenthood and helped to mitigate some of the negative impacts of this transition on incomes (Gregg et al., 2009).

However, Brewer et al. (2006) find Working Families Tax Credit would have increased lone parent employment by an additional two percentage points had it not been for simultaneous increases in cash benefits for families with children irrespective of employment. As part of its child poverty reduction strategy, Labour introduced a generous Child Tax Credit and substantial increases in Child Benefit and allowances for children within Council Tax Benefit and Housing Benefit. Furthermore, while the availability of Working Families Tax Credit at 16 hours increased the proportion of lone parents in 16 hour plus jobs, it also led to a reduction in average hours among full-timers (Gregg et al., 2009). Nevertheless, Labour's overall reforms did raise incomes for working lone parents by between 4 and 11 per cent, and for non-working lone parents by between 6 and 18 per cent, depending on the measure used (Adam and Browne, 2010).

\section{Conservative-Liberal Democrat Coalition (2010-5)}

In contrast to Labour, the Coalition's welfare-to-work discourse has largely downplayed broader economic and social structural explanations for worklessness. Under the influence of Conservative ideology and the Centre for Social Justice, the Coalition's rhetoric has instead closely followed the moral underclass discourse of conservative thinkers during the 1980s (Daguerre and Etherington, 2014). According to this discourse, while worklessness is rooted in behavioural factors, state benefits and the dependency they foster are ultimately to blame. The claim is that by allowing and promoting benefit dependency over participation in paid work, overgenerous and lenient benefits have created an "underclass" of welfare claimants who lack the proper work ethic of 
mainstream society (Murray, 1990). A prominent example of this discourse is found in Iain Duncan Smith's speech to the 2011 Conservative party conference:

To each person it [Labour's tax-benefit system] said: “you're financially better off out of work, better off playing the system”. They knew too many British people were on benefits living unproductive lives... A growing underclass was establishing itself, shut away, dysfunctional and too often violent.

A conception of "fairness" has further underpinned the Coalition's critique of welfare dependency. The Coalition argues on the one hand that reducing welfare dependency is about delivering "fairness" to claimants. This argument is based on a portrayal of welfare claimants as victims of the benefits system. The Coalition claims that by failing to make work pay, an wasteful and complex benefits system under Labour, comprising different out of work and in work benefits with varying withdrawal rates, has served to "trap" many claimants in inactivity and poverty (Hayton and McEnhill, 2014). On the other hand, the Coalition argues reducing welfare dependency is also about "fairness" for taxpayers. It argues Labour afforded non-working individuals a number of "advantages" over those in work by creating a lax benefits system that failed to adequately mirror life in the workplace (Daguerre and Etherington, 2014), and implementing excessive increases in out of work benefits despite slow wage growth following the 2008 global financial crisis (Osborne, 2012). The Coalition labels these apparent advantages as "unfair" by portraying non-working individuals as less morally upright than "hardworking taxpayers", who are "doing the right thing" by working and paying into the system (Daguerre and Etherington, 2014; Hayton and McEnhill, 2014). To this the Coalition adds reducing welfare dependency is also about "fairness" for future generations. It argues cutting the welfare bill to tackle the public sector deficit, which stood at $£ 155$ billion in 2010 
(Hansard, 2010), is not only economically prudent for securing future growth, but morally right for preventing the transmission of this debt to subsequent generations (Hayton and McEnhill, 2014).

In line with this discourse, the Coalition has implemented a number of benefit reforms designed to influence claimants' behaviour by encouraging employment while making it more difficult to remain inactive. Most notably, it has drastically cut the benefits attached to worklessness on the assumption this will steer claimants into work. Year-on-year, Child Benefit and levels of out of work support for Council Tax and housing costs have been frozen or increased either in line with a lower measure of inflation than under Labour, or by one per cent only. In addition, funding for Council Tax support has been cut by 10 per cent. Indeed, tax-benefit spending is projected to be $£ 16.7$ billion lower in 2015-6 than it would have otherwise been (Hood and Phillips, 2015) despite falling tax revenues following substantial increases in the point at which income tax becomes payable as pledged by the Liberal Democrats.

Yet the centrepiece of the Coalition's make work pay agenda is Universal Credit. Although by the time the Coalition leaves office few lone parents will be receiving it, it is set to be available in all UK Jobcentres by February 2016 (DWP, 2015). Universal Credit merges several out of work and in work benefits, namely Child Tax Credit, Housing Benefit, income-based Jobseeker's Allowance, income-related Employment and Support Allowance, Income Support and Working Tax Credit. Under Universal Credit, a lone mother's maximum entitlement comprises her standard allowance and elements for the first child and subsequent children, as well as additions for housing and any disabilities or caring responsibilities. For consistency, the Coalition has reformed support for Council Tax to use the same calculation of maximum entitlement. Like Working Tax 
Credit, Universal Credit also contains a childcare subsidy which is set to increase from 70 to 85 per cent of childcare costs from April 2016. Despite estimated implementation costs of $£ 1.8$ billion, the Coalition expects Universal Credit to deliver total net savings to government of $£ 5.3$ billion over 12 years (NAO, 2014) and annual savings thereafter of $£ 2.7$ billion through higher employment and reduced administration costs, error, fraud and overpayments (NAO, 2013).

According to the Coalition, Universal Credit will make even small amounts of work pay. This is firstly because Universal Credit removes the 100 per cent withdrawal rate for out of work benefits and replaces it with a lower one. Under Labour, a lone mother lost $£ 1$ of her out of work benefits for every $£ 1$ she earned over an earnings disregard of just $£ 20$ a week. In contrast, Universal Credit has a withdrawal rate of 65 per cent on net income. This means she loses 65 pence of her Universal Credit per $£ 1$ of net earnings gained after National Insurance and income tax. A second way in which Universal Credit is designed to make even short-hours jobs pay is through the extension of childcare subsidies to lone parents working fewer than 16 hours, who previously received no such help since Working Tax Credit was not available to them (DWP, 2010b).

The Coalition claims it will also pay to work longer and earn more under Universal Credit, as its single rate of withdrawal is lower than the combined rate by which Housing Benefit and tax credits were withdrawn under Labour. This means claimants should keep more of their money as they progress in work (DWP, 2010b). Under Labour, the combined withdrawal of Housing Benefit and tax credits meant a working lone mother potentially lost 90 pence to benefit withdrawal and in-work taxes of every additional $£ 1$ she earned from working longer or for higher pay. Under Universal Credit however, she potentially loses 76 pence of every additional $£ 1$ earned to benefit withdrawal and taxes. Appendix 
1 gives a worked example of how Universal Credit is calculated for one of the lone mothers included in the analysis.

In addition to making work pay, the Coalition has intensified the behavioural conditions attached to lone parents' benefit receipt. Lone Parent Obligations have been extended to those with a child aged five and six, delivering estimated net savings to the Exchequer of $£ 250$ million by March 2015 (DWP, 2011). Furthermore, 11 out of 12 of the lone parent flexibilities in Labour's Jobseeker's Allowance are either no longer legally binding, or are narrower in scope under Universal Credit. For example, Universal Credit regulations do not explicitly state that lone parents with a child aged five to 13 can still restrict their work availability to school hours even if no such jobs are available. Meanwhile, those with older children can no longer restrict their work availability according to their caring responsibilities unless jobs are available at the required hours (Gingerbread, 2013).

A further change to conditionality under Universal Credit is that working lone parents will continue to be subject to it until they are earning the equivalent of the National Minimum Wage multiplied by the number of hours they are expected to be available for work (Kennedy and McInnes, 2013). In 2015-16 prices, this is equivalent to $£ 130$ a week for those with a youngest child aged five to 12 years assuming a school-hours job of 20 hours a week. For lone parents with older children who are unable to find work at the hours they require to suit their caring responsibilities, the threshold is $£ 227.50$ assuming a 35 hour job. Any lone mother failing to reach these thresholds could have part of her Universal Credit award sanctioned for a minimum of four weeks up to a maximum of three years, depending on the nature of the offence and any previous non-compliance.

Correspondingly, the Coalition has placed less emphasis than Labour on improving employment supports to help address some of the broader economic and social structural 
barriers to lone parents' employment. The exception is its Work Programme, which replaces Labour's Flexible New Deal but seeks to offer lone parents the same personalized employment support. The main difference is it incorporates a greater role for non-state providers and market mechanisms (Rees et al., 2014) which the Coalition claims will deliver comparable employment outcomes to the Flexible New Deal, but at a two per cent lower cost (Lupton, 2015).

In summary, welfare-to-work policy discourse since 2010 has shifted further towards one which blames worklessness primarily on behavioural failings, exacerbated by welfare dependency. The Coalition has reinforced this critique of dependency by portraying it as unfair on welfare claimants and taxpayers and unaffordable in the current economic climate. In line with this discourse, it has relied primarily on reforming the tax-benefit system in order to make work pay and intensifying the conditions attached to benefit receipt in order to activate lone parents.

The remainder of this article examines whether the Coalition's tax-benefit reforms could make work pay for lone mothers. Existing projections based on representative data on actual lone parents show the reforms will likely reduce average incentives for nonworking lone parents to start work and have negligible impact on lone parent employment rates. At the same time, average incentives for those who are already working to increase their earnings are projected to increase, potentially leading to a seven per cent increase in total hours worked by lone parents and five per cent increase in their aggregate earnings (Adam and Browne, 2013; Adam and Phillips, 2013). The article builds on these projections by using hypothetical lone mothers to show how the impacts of the reforms on a lone mother's work incentives potentially vary according to her specific characteristics. This is to expose whether reforms have the potential to deliver on the 
Coalition's promise of making work pay for lone mothers under a range of different circumstances relevant to different groups of lone mothers. In particular, the analysis shows how tax burdens and benefit entitlements can vary with small increments in a lone mother's labour supply in order to highlight potential "anomalies" in the Coalition's reform agenda, whereby taking on additional hours beyond a certain point results in no, or only slight, income gains (Berger et al., 2001).

\section{Methods}

The analysis compares two hypothetical lone mothers' incentives under two different scenarios. The first scenario includes all changes to taxes and benefits implemented by the Coalition up to April 2015, in addition to Universal Credit ${ }^{1}$. Including Universal Credit in the first scenario gives a more encompassing illustration of how the Coalition has sought to regulate and control lone parents' employment behaviour through the design of its tax-benefit policies, as well as how effective its make work pay agenda could be for lone parents. For these same reasons, the analysis ignores any transitional protection, which is additional income to top up an individual's Universal Credit during the initial transition, and assumes Universal Credit covers 85 per cent of childcare costs as planned from April 2016, by which time it will be available nationwide.

The second scenario is the tax-benefit system as at April 2010 under Labour. Benefits included are Child Benefit, Child Tax Credit, Council Tax Benefit, Housing Benefit, Income Support, Jobseeker's Allowance and Working Tax Credit. For comparability, taxes and benefits under both scenarios have been adjusted to bring them in line with

\footnotetext{
${ }^{1}$ Data on the hypothetical lone mothers' incentives and incomes under 2015 taxes and benefits excluding Universal Credit are available from the author upon request.
} 
2015-6 prices according to relevant convention or statute, using either historic or projected rates of inflation (Appendix 2).

Because the analysis is based on two hypothetical biographies, the results are not statistically representative of the UK lone mother population at large and cannot capture its full heterogeneity (Meyer et al., 2007). Using hypothetical biographies also means formal rules and laws have to be followed even though non-take up (Table 1) can affect real-life incentives (Atkinson and Marlier, 2009; Bradshaw, 2010). The analysis therefore does not summarize actual work incentives for the lone parent population under the Coalition. Rather, it shows how the Coalition's tax-benefit instruments potentially affect work incentives according to a lone parent's particular characteristics.

Table 1. Percentage of lone parents who claim the benefits they are entitled to by benefit type

\begin{tabular}{lcc}
\hline \hline & & \multicolumn{1}{c}{ Annual take-up } \\
Benefit & Year & rate (\%) \\
\hline Child Benefit & $2011-2$ & $95-96$ \\
Council Tax Benefit & $2009-10$ & $80-89$ \\
Housing Benefit & $2009-10$ & $86-92$ \\
Income Support & $2009-10$ & $84-92$ \\
Jobseeker's Allowance & N/A & Data unavailable \\
Tax credits & 2011-2 & $95-100$ \\
\hline Notes: Data for Jobseeker’s Allowance take-up rates are
\end{tabular}


The two biographies are:

- Katherine, who has two children. She pays $£ 8.36$ to a child-minder per hour she works outside of normal school hours during term-time for 38 weeks of the year, and $£ 4.72$ to a holiday club per hour worked during school holidays (Appendix 2). Calculations are based on average weekly childcare costs across the year.

- Rosie, who has one child and does not pay for childcare.

The biographies differ in two main respects. They firstly differ in relation to the number of children they have in order to reflect the situations of the majority of lone mothers in the UK today. Like 30 per cent of lone parents, Katherine has two children, and like 58 per cent, Rosie has one child (ONS, 2015). Secondly, whereas Katherine pays for childcare, Rosie does not. This is to illustrate how incentives under the reforms potentially vary according to whether or not work incurs childcare costs, as a survey recently showed one-quarter of lone parents do not work and one-third work under 35 hours because they cannot afford the childcare (Borg and Stocks, 2013). Accordingly, Katherine, like 60 per cent of working lone mothers in the UK, pays for formal childcare. On the other hand, Rosie pays no childcare costs to reflect that 40 per cent of working lone mothers said in a recent survey they do not require childcare (Maplethorpe et al., 2010). This is presumably because their children are either in school or old enough to no longer require supervision.

The analysis also calculates the biographies' incomes and incentives under a range of working hours to help identify potential "anomalies" in the Coalition's tax-benefit system, whereby taking on additional hours of work results in no, or only slight, income gains (Berger et al., 2001). In addition, their incentives are measured under two different rates of hourly pay: the National Minimum Wage to reflect the concentration of lone 
parents in low-paying jobs; and the median hourly wage for all female employees in the UK given the Coalition's aim of helping people progress to higher pay (see for example DWP, 2010a).

To isolate the influence of number of children, childcare costs, labour supply and hourly wage on the biographies' incentives and incomes, the analysis assumes they pay the same Council Tax and housing costs. These rates, in addition to Katherine's childcare costs, derive from national averages (Appendix 2). Housing costs are based on average rates in the social-rented sector to reflect that almost two-thirds of lone parents rent and that of these, 70 per cent are in social housing (Maplethorpe et al., 2010). The analysis further assumes both biographies are over 25 as the most recent available data shows 88 per cent of lone mothers are 25 years or older (ONS, 2003). Because the focus is on the income incentives to work created by the tax-benefit system, it is assumed the biographies do not have savings or receive child maintenance. While these factors can affect a lone parent's financial work incentives, the added complexity and specificity of such assumptions would only take the biographies further from the situations of real lone mothers (Heikkilä and Kuivalainen, 2002).

The analysis measures two types of financial work incentive. The first, the incentive to be in paid work, is measured by the biographies' participation tax rates:

\footnotetext{
1 - take home income in work after benefits, taxes and childcare costs - out of work income from benefits

total gross earnings from work
}

To illustrate: a lone mother with total gross earnings of $£ 300$ takes home $£ 200$ after benefit withdrawal, taxes and childcare costs. This compares to benefits when out of work of $£ 170$. The lone mother's participation tax rate is therefore: 


$$
1-\frac{£ 200-£ 170}{£ 300}=0.9
$$

In other words, she loses 90 per cent of her total gross earnings from working to benefit withdrawal, taxes and childcare costs. High participation tax rates therefore indicate weak incentives to be in employment.

The second, the incentive to take on additional hours when in work, is measured by the biographies' effective marginal tax rates:

$$
1 \text { - } \frac{\text { change in take home income from taking on } x \text { additional hours of work at a given rate of hourly pay }}{\text { change in gross earnings from taking on } x \text { additional hours }}
$$

To illustrate: a lone mother in a minimum wage job of $£ 6.50$ an hour increases her hours by 10 a week, giving additional gross earnings of $£ 65$. However, her take-home income increases by just $£ 13$. Her effective marginal tax rate is therefore:

$$
1-\frac{£ 13}{£ 65}=0.8
$$

This means she loses 80 per cent of the extra earnings gained from taking on 10 additional hours of work at minimum wage to benefit withdrawal, increasing tax liabilities and/or additional childcare costs. High effective marginal tax rates thus indicate weak incentives to take on additional hours. 


\section{Results}

Figure 1. Participation tax rates in a minimum wage job ( $£ 6.50$ an hour) under Labour and the Coalition.



Note: The participation tax rate measures the incentive to be in paid work and is measured by: 1 - [(take home income when in work out of work income from benefits) $\div$ total gross earnings from working].

Source: Own calculations (Appendix 2)

Figure 2. Participation tax rates in an average wage job ( $£ 10.42$ an hour) under Labour and the Coalition.

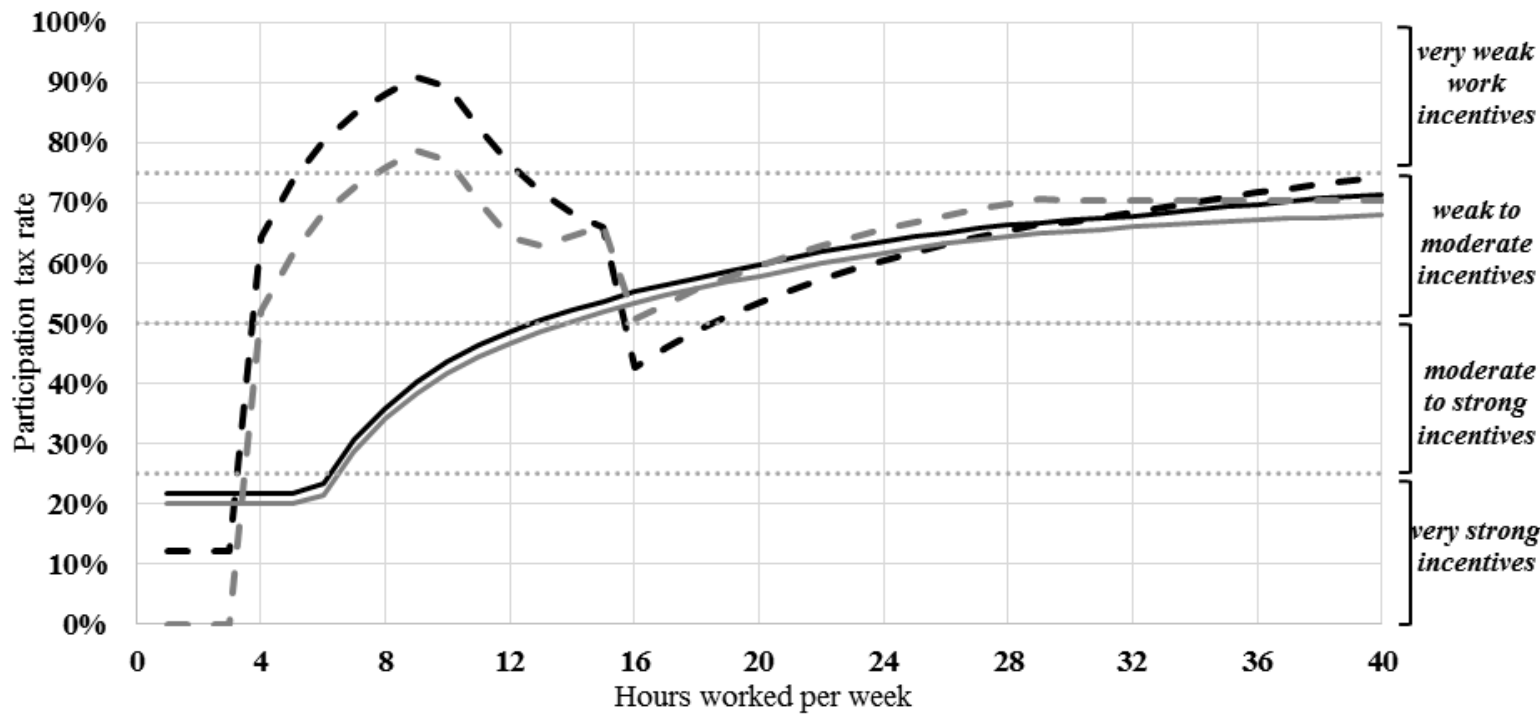

\footnotetext{
Katherine (two children, pays for childcare) under the Coalition - Katherine under Labour

Rosie (one child, no childcare costs) under the Coalition _ - Rosie under Labour
}

Note: The participation tax rate measures the incentive to be in paid work and is measured by: $1-[$ (take home income when in work out of work income from benefits ) $\div$ total gross earnings from working].

Source: Own calculations (Appendix 2). 
Figure 3. Total weekly net income in a minimum wage job ( $£ 6.50$ an hour) under Labour and the Coalition.

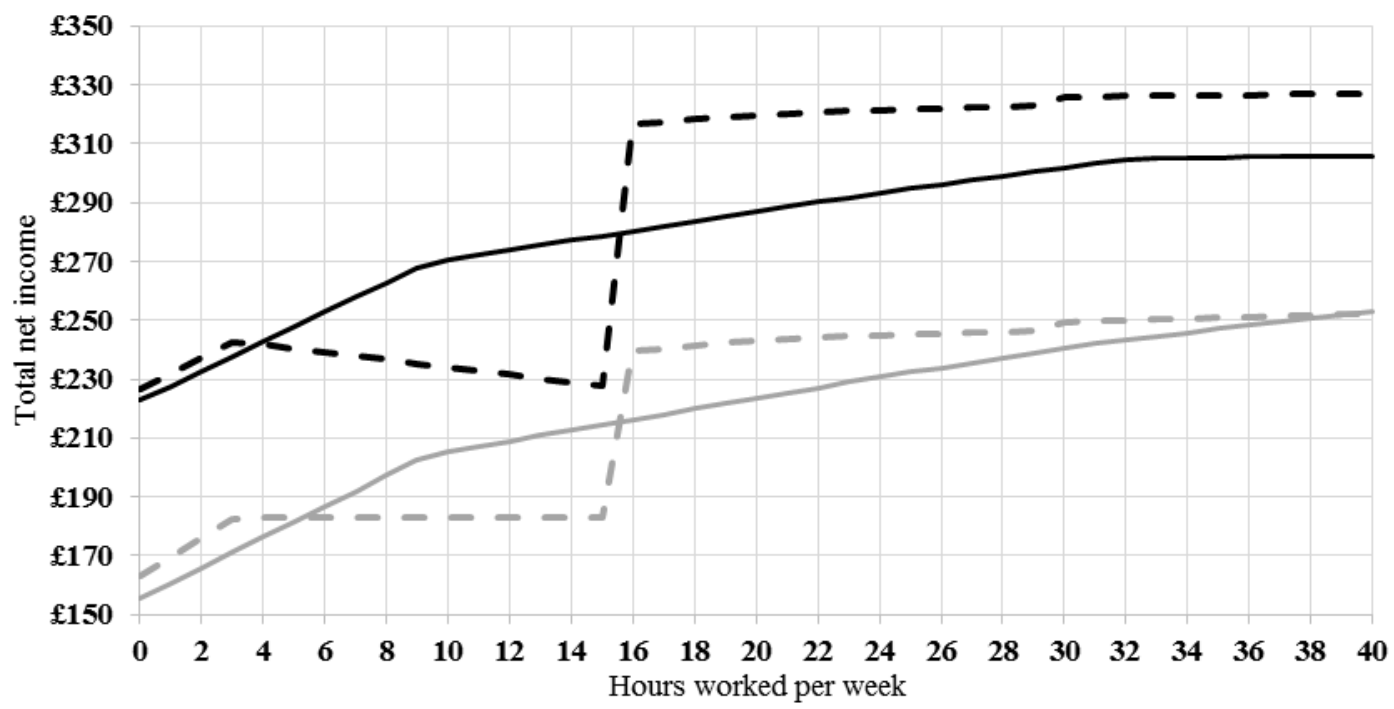

Katherine (two children, pays for childcare) under the Coalition - Katherine under Labour
Rosie (one child, no childcare costs) under the Coalition - Rosie under Labour

Note: Total net income is all income from benefits and/or earnings after deductions for rent, Council Tax and any in-work taxes and childcare costs. Please note the vertical axis starts at $£ 150$ rather than at zero to make it easier to see small changes in income. Source: Own calculations (Appendix 2).

Figure 4. Total weekly net income in an average wage job ( $£ 10.42$ an hour) under Labour and the Coalition.

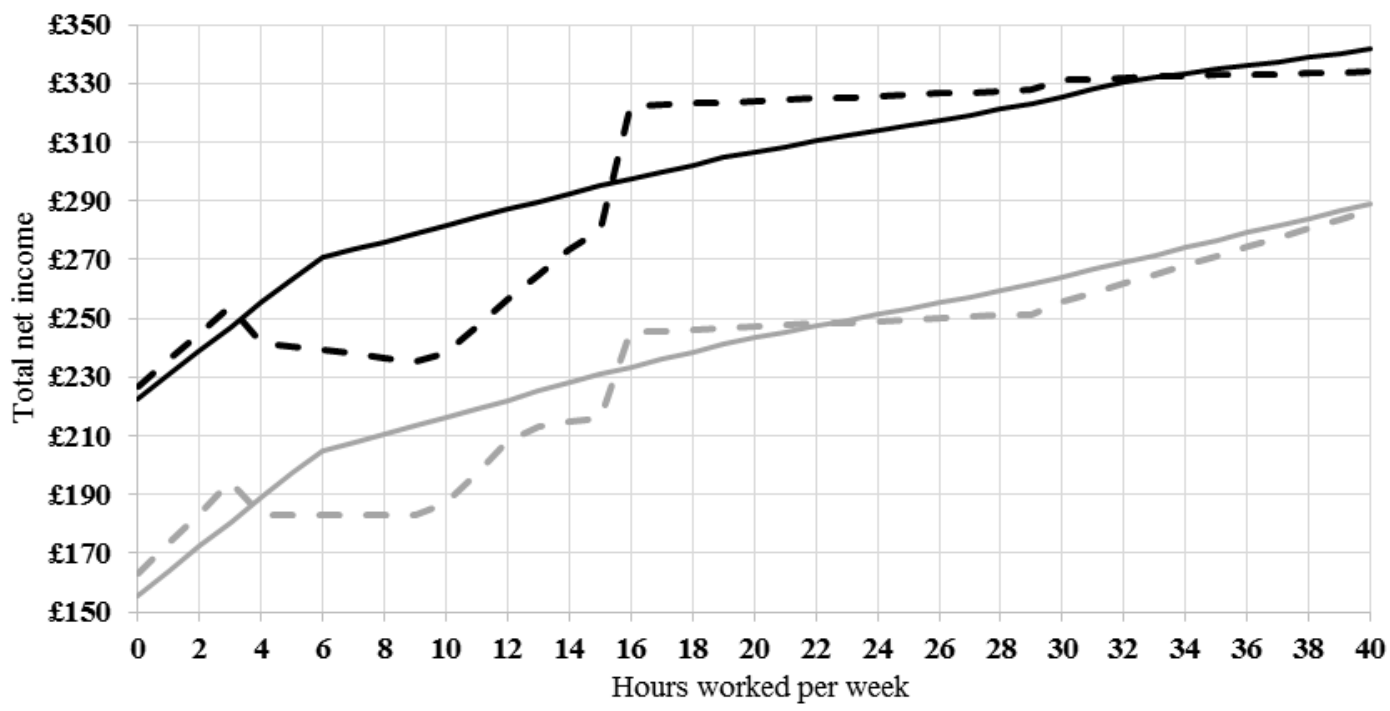

Katherine (two children, pays for childcare) under the Coalition
- Rosie under Labour

Rosie (one child, no childcare costs) under the Coalition

Note: Total net income is all income from benefits and/or earnings after deductions for rent, Council Tax and any in-work taxes and childcare costs. Please note the vertical axis starts at $£ 150$ rather than at zero to make it easier to see small changes in income. Source: Own calculations (Appendix 2). 
To give a measure of the biographies' financial incentives to be in paid work, figure 1 shows their participation tax rates (PTRs) under Labour and the Coalition according to hours worked in a minimum wage job. Figure 2 shows the same as for figure 1 but for an average wage job. In both figures, the solid lines represent the biographies' PTRs under the Coalition, while the dashed lines represent their PTRs under Labour. The further the lines sit above the horizontal axis at zero per cent, the higher their PTRs, and so the weaker their incentives to be in paid work. Conversely, the closer the lines sit to the horizontal axis, the stronger their financial incentives to work.

Figures 3 gives the biographies' budget constraints when in a minimum wage job, while figure 4 gives their budget constraints in an average wage one. A budget constraint plots hours worked against income from earnings and benefits net of any taxes and childcare costs to illustrate how an individual's income varies according to hourly increments in his or her labour supply. The slope of the budget constraint therefore gives a measure of the biographies' effective marginal tax rates (EMTRs), which provide a measure of the incentives to take on additional hours of work. A positive gradient indicates net income is increasing with each additional hour of work taken on. Consequently, the steeper the positive gradient, the more the biographies keep of an increase in earnings from working longer. Steep positive gradients correspondingly indicate low EMTRs and therefore strong incentives to increase labour supply.

The figures illustrate the biographies' incentives to work in a mini-job of 4 to 15 hours improve substantially and become strong under the Coalition (figures 1 and 2). Total net incomes when in a mini-job have also increased significantly (figures 3 and 4). For instance, Katherine's PTR at 15 hours for a minimum wage job has fallen from 99 per cent under Labour to 43 per cent under the Coalition (black lines in figure 1); in other 
words, by 56 percentage points. In addition, her total net income has increased from $£ 228$ under Labour to $£ 279$ under the Coalition (black lines in figure 3), which is an income gain of $£ 51$ or 22 per cent. Similarly, Rosie’s PTR at 15 hours for a minimum wage job has fallen from 79 to 40 per cent (grey lines in figure 1), or by 39 percentage points, while her income has risen from $£ 183$ to $£ 214$ (grey lines in figure 3 ), which is a gain of $£ 31$ or 17 per cent.

Stronger incentives to work in a mini-job result from Universal Credit's lower withdrawal rate compared to the Income Support and Jobseeker's Allowance it replaces, as well as the extension of childcare subsidies to those working fewer than 16 hours. Katherine's work incentives and net income between four and 15 hours have therefore improved the most since she pays for childcare but Rosie does not. A more generous element for Katherine's second child in Universal Credit compared to Labour's Child Tax Credit, equivalent to $£ 5.86$ in $2015-6$ prices, also explains why Katherine's income when out of work or in a mini-job has improved to a greater extent than for Rosie.

On the other hand, the biographies' incentives to work fewer than four hours have weakened slightly under the Coalition. This is because whereas Labour's Council Tax Benefit disregarded some earnings before it started to be withdrawn, the Coalition's new system of support for Council Tax does not disregard any earnings before it starts to be reduced by 20 pence for every $£ 1$ earned. Nevertheless, because support for Council Tax is the only benefit that starts to be withdrawn when working under four hours, the biographies' incentives under the Coalition remain very strong in absolute terms (solid lines in figures 1 and 2).

While the Coalition's proposed tax-benefit reforms clearly give strong incentives for the biographies to work in short-hours jobs, the impacts on their incentives to work in a job 
longer than 16 hours are more mixed. Compared to under Labour, incentives to work 16 hours plus under the Coalition are at best marginally stronger, and at worst substantially weaker.

The drop in incentives to be in paid work is sharpest at exactly 16 hours due to the removal of Labour's Working Tax Credit. For instance, for a minimum wage job, Katherine's PTR has risen from 14 per cent under Labour to 45 per cent under the Coalition; that is, by 31 percentage points (black lines in figure 1). Correspondingly, her total net income has fallen from $£ 316$ to $£ 280$, which is a decrease of $£ 36$ or 11 per cent (black lines in figure 3). Meanwhile, Rosie's PTR for a 16 hour minimum wage job has risen from 26 to 42 per cent, or by 16 percentage points (grey lines in figure 1), while her total net income has fallen from $£ 240$ to $£ 216$, which is a drop of $£ 24$ or 10 per cent (grey lines in figure 3 ). PTRs for a 16 hour job at average wage have also increased under the Coalition, but to a smaller degree: namely, 12 percentage points for Katherine and two percentage points for Rosie (figure 2). This is because Labour's Working Tax Credit gave exceptionally strong incentives to take a minimum wage job. Its generous earnings disregard in combination with low earnings meant the biographies kept most, if not all, of their maximum entitlement to tax credits. They were however still better off in absolute terms under Labour when in a 16 hours plus job that paid the average rather than minimum wage (figures 3 and 4).

While PTRs at 16 hours or slightly longer are far weaker and incomes far lower under the Coalition's reforms than before, there are smaller changes in PTRs and incomes at longer hours of work. Figures 1 to 4 show a gradual narrowing of the gap in PTRs and incomes between Labour and the Coalition as working hours go up. This is partly down to aboveindexation increases in the earnings threshold at which income tax becomes payable 
under the Coalition. These mean the biographies start paying tax at 32 rather than at 24 hours in a minimum wage job and at 20 instead of 15 hours in an average wage one. They also lose $£ 10.55$ less of their earnings to tax in 2015-6 prices when they do start paying it.

Smaller changes in PTRs and incomes at longer working hours are also down to Universal Credit. Although Universal Credit removes Working Tax Credit and the income boost it gave at 16 hours, its lower withdrawal rate relative to Housing Benefit and tax credits in combination means the Coalition gives similar, if not slightly better, incentives and incomes to Labour the more hours the biographies work beyond 16. For example, in 20156 prices, Katherine's income under Labour from Housing Benefit and tax credits when in an average wage job fell by $£ 69.10$ when she increased her hours from 16 to 40 ; in contrast, her income from Universal Credit falls by $£ 50.60$.

Another notable feature of figures 3 and 4 is Katherine's income when in a 16 hours plus job has fallen to a greater extent under the Coalition than for Rosie. For instance, for a 40 hour job at minimum wage, Katherine’s total net income has fallen from $£ 327$ under Labour to $£ 306$ under the Coalition, representing an income loss of $£ 21$ (black lines in figure 3). Conversely, Rosie's income has decreased by just 98 pence (grey lines in figure 3). The difference between the biographies is explained by lower elements for subsequent children under the Coalition's benefits compared to Labour's benefits, which affect Katherine because she has two children. Elements for subsequent children in Child Benefit are $£ 2.50$ lower under the Coalition in 2015-6 prices, while those in Universal Credit and support for Council Tax are $£ 10.34$ lower than in Labour's Housing Benefit and Council Tax Benefit. 
In terms of the biographies incentives' to take on additional hours when they already have jobs, figures 3 and 4 show an overall improvement from Labour to the Coalition. This is shown by the fact the biographies' budget constraints are, for the most part, more positive sloping under the Coalition than under Labour. Universal Credit's lower withdrawal rate relative to the pound-for-pound withdrawal of the out of work benefits it replaces, together with the availability of help with childcare costs at all working hours, have improved the biographies' incentives to increase their hours beyond a few up to 15 a week. At the same time, its lower withdrawal rate compared to Housing Benefit and tax credits combined in conjunction with its higher childcare subsidy compared to Working Tax Credit have increased the biographies' incentives to take on additional hours beyond 16 a week.

Yet the problem with the Coalition's welfare reform agenda is that in absolute terms, the biographies' incentives to work beyond just a short number of hours a week remain inadequate. PTRs at minimum wage under the Coalition start to exceed 50 per cent above 20 hours' work for Katherine and 22 for Rosie, indicating they lose more than half of their total earnings to benefit withdrawal, taxes and/or childcare costs (solid lines in figure 1). Incentives to work correspondingly enter the moderate to weak zone. PTRs at average wage begin to surpass 50 per cent once hours exceed just 12 for Katherine and 14 for Rosie (solid lines in figure 2).

Moreover, the incentives for the biographies when they are already in work to take on additional hours beyond just nine at minimum wage and six at average wage remain weak in absolute terms under the Coalition. Their budget constraints from these points start to flatten, indicating only small income gains from each additional hour of work taken on beyond these hours (solid lines in figures 3 and 4). This is mainly because these are the 
hours from which Universal Credit starts to be withdrawn. The combined withdrawal of Universal Credit and support for Council Tax gives EMTRs of 72 per cent for Rosie and 75 per cent for Katherine due to her childcare costs. EMTRs then rise by an additional three per cent when National Insurance becomes payable from 25 hours at minimum wage and 16 at average wage, and by a further six per cent when the biographies start paying income tax from 32 hours at minimum wage and 21 at average wage. Because she pays for childcare, EMTRs for Katherine from 32 hours are exceptionally high, reaching 98 per cent at minimum wage and 87 per cent at average wage. This is because the analysis assumes that by working longer than 32 hours a week, Katherine would be working outside of normal school hours and so would start paying for childcare during term-time.

\section{Conclusion}

Since the 1990s, make work pay measures have been a key policy lever for getting more lone parents into work and earning more. While Labour sought to make work pay mainly by increasing in-work benefits, the Coalition has instead focused on cutting out of work support and simplifying the benefits systems to help lone parents keep more of their earnings. This has been underpinned by a discourse which claims an apparently overgenerous and complicated benefits system under Labour not only created worklessness by eroding the "work habit", but was "unfair" on both welfare claimants and taxpayers and no longer affordable given deficit reduction plans.

Yet for the two hypothetical lone mothers in this analysis, while incentives to work in a mini-job of fewer than 16 hours have improved, incentives to work longer appear weak if not weaker than under Labour. In fact, the financial returns to progressing in work begin to diminish once hours exceed just six at average wage and nine at minimum wage, the hours from which the Coalition's flagship make work pay reform, Universal Credit, starts 
to be withdrawn. This suggests Universal Credit's withdrawal rate may be set too high to make more than only small amounts of work pay.

On the other hand, the introduction of in work conditionality until lone parents are working "enough" hours will likely push many into working longer even if it does not pay (Whitworth and Griggs, 2013). Although Labour similarly used conditionality to push certain lone parents into jobs of 16 hours, the analysis shows these jobs paid for the hypothetical lone mothers through Working Tax Credit. In contrast, the Coalition's overriding goal of reducing benefit dependency means tougher conditionality will potentially push lone parents into working beyond the point of financial returns.

Yet the abilities of lone parents to meet increased demands and expectations are likely to be undermined by broader policy and economic changes. Early evidence suggests the Coalition's Work Programme is not meeting lone parents' specific needs, and they are a third less likely than other groups to find work through it (Dewar, 2012; Whitworth, 2013). In addition, spending on early intervention, education and childcare fell by a quarter between 2009-10 and 2012-3 (Stewart and Obolenskaya, 2015), while 37 per cent of local authorities have reported cuts to provision of after-school clubs and 44 per cent have reported reductions in breakfast clubs (Wintour, 2013). Furthermore, lone parent underemployment, measured by total hours worked as a percentage of preferred hours of work, rose by 51 per cent between 2007 and 2012 throughout the recession (Tinsley, 2014). In summary, whereas Labour's welfare-to-work reforms helped to raise lone parent employment and incomes, diminishing financial returns to working beyond a short number of hours under the Coalition, in conjunction with tougher conditionality and reduced employment supports, could have the opposite effect, especially given the rise in short-hours and insecure forms of employment following the recession. 


\section{Acknowledgements}

This work was undertaken as part of doctoral research funded by an Economic and Social Research Council 1+3 Studentship Award. I am extremely grateful to my supervisors Professor Traute Meyer and Professor Ann Berrington for their valuable support and constructive feedback, and to the journal editors and three anonymous referees for their helpful comments which greatly improved the work. 


\section{References}

Adam, S. and Browne, J. (2010) 'Redistribution, work incentives and thirty years of UK tax and benefit reform', Institute for Fiscal Studies Working Paper No. 10/24, London: IFS, http://socialwelfare.bl.uk/subject-areas/services-activity/povertybenefits/instituteforfiscalstudies/132531wp1024[2].pdf [accessed 22.02.15].

Adam, S. and Browne, J. (2013) 'Do the UK government's welfare reforms make work pay?', Institute for Fiscal Studies Working Paper No. W13/26, London: IFS, http://www.ifs.org.uk/wps/wp1326.pdf [accessed 27.03.15].

Adam, S. and Phillips, D. (2013) 'An ex-ante analysis of the effects of the UK government's welfare reforms on labour supply in Wales', Institute for Fiscal Studies Report No. R75, London: IFS, http://www.ifs.org.uk/comms/r75.pdf [accessed 27.03.15].

Atkinson, A. B. and Marlier, E. (2009) 'Analysing and measuring social inclusion in a global context', New York: United Nations, http://www.un.org/esa/socdev/publications/measuring-social-inclusion.pdf [accessed 27.03.15].

Bell, A., Finch, N., La Valle, I., Sainsbury, R. and Skinner, C. (2005) 'A question of balance: lone parents, childcare and work', Department for Work and Pensions Research Report No. 230, Leeds: Corporate Document Services, http://www.york.ac.uk/inst/spru/pubs/pdf/rrep230.pdf [accessed 27.03.15].

Berger, F., Borsenberger, M., Immervoll, H., Lumen, J., Scholtus, B. and De Vos, K. (2001) 'The impact of tax-benefit systems on low-income households in the benelux countries. A simulation approach using synthetic datasets', EUROMOD Working Paper No. EM3/01, Cambridge: Department of Applied Economics, Cambridge University, http://128.118.178.162/eps/mic/papers/0302/0302003.pdf [accessed 27.03.15]. 
Borg, I. and Stocks, A. (2013) 'A survey of childcare and work decisions among families with children', Department for Work and Pensions Working Paper No. 114, London:

DWP, https://www.gov.uk/government/uploads/system/uploads/attachment_data/file/2 21221/WP114.pdf [accessed 7 August 2014].

Bradshaw, J. (2010) 'An international perspective on child benefit packages', in $\mathrm{S}$. Kamerman, S. Phipps and A. Ben-Arieh (eds.), From child welfare to child wellbeing: an international perspective on knowledge in the service of policy making, Dordrecht: Springer, 293-307.

Brewer, M., Browne, J. and Jin, W. (2012a) 'Benefit integration in the UK: an ex ante analysis of Universal Credit', in T. Callan (ed.), Budget perspectives 2013, Dublin: The Economic and Social Research Institute, 25-48.

Brewer, M., Browne, J. and Jin, W. (2012b) 'Universal Credit: a preliminary analysis of its impact on incomes and work incentives', Fiscal Studies, 33, 1, 39-71.

Brewer, M. and De Agostini, P. (2015) 'Credit crunched: single parents, Universal Credit and the struggle to make work pay', EUROMOD Working Paper No. EM 3/15, Colchester: Institute for Social and Economic Research, University of Essex, https://www.iser.essex.ac.uk/research/publications/workingpapers/euromod/em3-15.pdf [accessed 01.04.15].

Brewer, M., Duncan, A., Shephard, A. and Suárez, M. J. (2006) 'Did working families' tax credit work? The impact of in-work support on labour supply in Great Britain', Labour Economics, 13, 6, 699-720.

Browne, J. (2012) 'The impact of austerity measures on households with children', London: Family and Parenting Institute, 
http://www.theministryofparenting.com/wp-

content/uploads/2012/05/FPI_IFS_Austerity_Jan_2012.pdf [accessed 01.04.15].

Daguerre, A. and Etherington, D. (2014) 'Welfare reform in the UK under the Conservative-led Coalition government: ruptures and continuities', Working Paper, London: $\quad$ Middlesex $\quad$ University, http://workfare.org.uk/images/uploads/docs/Welfare_Reform_in_the_UK_PubR eady.pdf [accessed 01.04.15].

De Agostini, P. and Brewer, M. (2013) 'Credit crunched: single parents, Universal Credit and the struggle to make work pay', London: Gingerbread, http://www.gingerbread.org.uk/content/1933/Credit-crunched [accessed 01.04.15].

Deacon, A. (2003) '"Levelling the playing field, activating the players": New Labour and the "cycle of disadvantage"', Policy and Politics, 31, 1, 123-37.

Department for Work and Pensions (2012) 'Income-related benefits: estimates of take-up in 2009-10', London: DWP, https://www.gov.uk/government/uploads/system/uploads/attachment_data/file/2 22915/tkup_full_report_0910.pdf [accessed 01.04.15].

Dewar, L. (2012) 'Is the Work Programme working for single parents? An analysis of the experience of single parents moving onto the Work Programme', Bristol: Single Parent Action Network, https://spanuk.files.wordpress.com/2012/07/final-workprog-ib-1502-11.pdf [accessed 22.02.15].

Driver, S. and Martell, L. (1999) 'New Labour: culture and economy', in L. Ray and A. Sayer (eds.), Culture and economy after the cultural turn, London: Sage, 246-69.

Duncan, S. and Edwards, R. (1999) Lone mothers, paid work and gendered moral rationalities, Basingstoke: Macmillan. 
Duncan Smith, I. (2011) 'Iain Duncan Smith speech in full', 3 October, http://www.politics.co.uk/comment-analysis/2011/10/03/iain-duncan-smithspeech-in-full [accessed 04.04.15].

DWP (2007) 'Ready for work: full employment in our generation', Cm 7290, London: The Stationery Office, https://www.gov.uk/government/uploads/system/uploads/attachment_data/file/2 43122/7290.pdf [accessed 01.04.15].

DWP (2010a) '21st century welfare', Cm 7913, London: The Stationery Office, https://www.gov.uk/government/uploads/system/uploads/attachment_data/file/1 81139/21st-century-welfare_1_.pdf [accessed 01.04.15].

DWP (2010b) 'Universal Credit: welfare that works', Cm 7957, London: The Stationery Office, https://www.gov.uk/government/uploads/system/uploads/attachment_data/file/4 8897/universal-credit-full-document.pdf [accessed 01.04.15].

DWP (2011) 'Conditionality measures in the 2011 Welfare Reform Bill', London: DWP, https://www.gov.uk/government/uploads/system/uploads/attachment_data/file/2 20184/conditionality-wr2011-ia.pdf [accessed 01.04.15].

DWP $(2015)$ 'Universal Credit makes work pay', https://www.gov.uk/government/news/universal-credit-makes-work-pay [accessed 10.04.15].

Freud, D. (2011) 'Speech: health and wellbeing', 6 October, https://www.gov.uk/government/speeches/health-and-wellbeing [accessed 05.02.15].

Ghelani, D. and Stidle, L. (2014) 'Universal Credit: towards an effective poverty reduction strategy', London: Policy in Practice, http://policyinpractice.co.uk/wp- 
content/uploads/2014/06/Universal-Credit-A-Review-by-Policy-in-Practice.pdf

[accessed 01.04.15].

Gingerbread (2013) 'Job seeking requirements for single parents under Universal Credit: briefing note for parliamentarians on the Universal Credit regulations 2013', London: Gingerbread, http://www.gingerbread.org.uk/content/663/Policy-work--benefits [accessed 01.04.15].

Gregg, P., Harkness, S. and Macmillan, L. (2006) 'Welfare to work policies and child poverty: a review of issues relating to the labour market and economy', York: Joseph Rowntree Foundation, http://www.jrf.org.uk/sites/files/jrf/9781859355107.pdf [accessed 01.04.15].

Gregg, P., Harkness, S. and Smith, S. (2009) 'Welfare reform and lone parents in the UK', The Economic Journal, 119, February, F38-F65.

Hansard (2010) HC Deb, vol. 512, col. 39, 21 June, http://www.publications.parliament.uk/pa/cm201011/cmhansrd/cm100621/debte xt/100621-0006.htm [accessed 06.02.15].

Harkness, S. and Skipp, A. (2013) 'Lone mothers, work and depression', London: Nuffield Foundation, http://www.nuffieldfoundation.org/sites/default/files/files/Lone $\% 20$ mothers, $\% 2$ 0work\%20and\%20depression.pdf [accessed 01.04.15].

Haux, T. (2011) 'Lone parents and the Conservatives: anything new?', in C. Holden, M. Kilkey and G. Ramia (eds.), Social policy review 23: analysis and debate in social policy, 2011, Bristol: Policy Press, 147-64.

Haux, T. (2012) 'Activating lone parents: an evidence-based policy appraisal of welfareto-work reform in Britain', Social Policy and Society, 11, 1, 1-14. 
Hayton, R. and McEnhill, L. (2014) 'Rhetoric and morality - how the Coalition justifies welfare policy', in J. Atkins, A. Finlayson, J. Martin and N. Turnbull (eds.), Rhetoric in British politics and society, Basingstoke: Palgrave Macmillan, 10115.

Heikkilä, M. and Kuivalainen, S. (2002) 'Using social benefits to combat poverty and social exclusion: opportunities and problems from a comparative perspective: European synthesis report', Trends in Social Cohesion Report No. 3, Strasbourg: Council

of Europe, http://www.coe.int/t/dg3/socialpolicies/socialcohesiondev/source/Trends/Trends -03_en.pdf [accessed 01.04.15].

Hirsch, D. (2012) 'Struggling to make ends meet: single parents and income adequacy under Universal Credit', London: Gingerbread, http://www.gingerbread.org.uk/content/686/Research-reports $\quad$ [accessed 01.04.15].

HMRC (2013) 'Child Benefit, Child Tax Credit and Working Tax Credit take-up rates 2011-12', London: Her Majesty's Revenue and Customs, https://www.gov.uk/government/uploads/system/uploads/attachment_data/file/2 65488/cwtcchb-take-up2011-12_fin.pdf [accessed 01.04.15].

Hood, A. and Phillips, D. (2015) 'Benefit spending and reforms: the Coalition government's record', Institute for Fiscal Studies Briefing Note No. BN160, London: IFS, http://www.ifs.org.uk/uploads/publications/bns/BN160.pdf [accessed 01.04.15].

Immervoll, H., Marianna, P. and D'Ercole, M. M. (2004) 'Benefit coverage rates and household typologies: scope and limitations of tax-benefit indicators', OECD Social, Employment and Migration Working Paper No. 20, Paris: Organization 
for Economic Co-operation and Development, http://www.oecd.org/eu/34440014.pdf [accessed 01.04.15].

Kennedy, S. (2010) 'Lone parents and Jobseeker's Allowance', House of Commons Library Standard Note No. SN/SP/5532, London: House of Commons, http://www.parliament.uk/briefing-papers/SN05532/lone-parents-andjobseekers-allowance [accessed 01.04.15].

Kennedy, S. and McInnes, R. (2013) 'Draft Universal Credit regulations 2013', House of Commons Library Standard Note No. SN06548, London: House of Commons, http://www.parliament.uk/business/publications/research/briefingpapers/SN06548/draft-universal-credit-regulations-2013 [accessed 01.04.15].

Lewis, J. (1998) 'The problem of lone-mother families in twentieth-century Britain', Journal of Social Welfare and Family Law, 20, 3, 251-83.

Lister, R. (1999) "Reforming welfare around the work ethic': new gendered and ethical perspectives on work and care', Policy \& Politics, 27, 2, 233-46.

Lister, R. (2002) 'The responsible citizen: creating a new British welfare contract', in C. Kingfisher (ed.), Western welfare in decline: globalization and women's poverty, Pennslyvania: University of Pennslyvania Press, 111-27.

Lupton, R. (2015) 'The Coalition's social policy record: policy, spending and outcomes 2010-2015', Social Policy in a Cold Climate Research Report No. 4, London: Centre for Analysis of Social Exclusion, London School of Economics, http://sticerd.lse.ac.uk/dps/case/spcc/rr04.pdf [accessed 01.04.15].

Maplethorpe, N., Chanfreau, J., Philo, D. and Tait, C. (2010) 'Families with children in Britain: findings from the 2008 Families and Children Study (FACS)', Department for Work and Pensions Research Report No. 656, London: DWP, 
https://www.gov.uk/government/uploads/system/uploads/attachment_data/file/2 14426/rrep656.pdf [accessed 01.04.15].

Meyer, T., Bridgen, P. and Riedmüller, B. (2007) Private pensions versus social inclusion? Non-state provision for citizens at risk in Europe, Cheltenham: Edward Elgar.

Millar, J. (2010) 'Lone mothers, poverty and paid work in the United Kingdom', in S. Chant, $\mathrm{H}$ (ed.), The international handbook of gender and poverty: concepts, research, policy, Cheltenham: Edward Elgar, 147-52.

Morel, N., Palier, B. and Palme, J. (2012) 'Beyond the welfare state as we knew it?', in N. Morel, B. Palier and J. Palme (eds.), Towards a social investment state? Ideas, policies and challenges, Bristol: Policy Press, 1-30.

Murray, C. (1990) The emerging British underclass, London: Institute of Economic Affairs Health and Welfare Unit.

NAO (2013) 'Universal Credit: early progress', HC 621, London: The Stationery Office, http://www.nao.org.uk/wp-content/uploads/2013/09/10132-001-Universalcredit.pdf [accessed 01.04.15].

NAO (2014) 'Universal Credit: progress update', HC 786, London: The Stationery Office, http://www.nao.org.uk/wp-content/uploads/2014/11/Universal-Credit-progressupdate.pdf [accessed 01.04.15].

ONS (2003) 'Census 2001 national report for England and Wales', London: The Stationery Office, http://www.ons.gov.uk/ons/rel/census/census-2001-national$\underline{\text { report-for-england-and-wales/national-report-for-england-and-wales-part- }}$ 1/index.html [accessed 01.04.15]. 
ONS (2011) 'Census: aggregate data (England and Wales)', http://infuse2011.mimas.ac.uk/InFuseWiz.aspx?cookie=openaccess $\quad$ [accessed 08.05.14].

ONS (2013) 'Working and workless households, 2013', Table P, http://www.ons.gov.uk/ons/publications/re-reference-

tables.html?edition=tcm\%3A77-322240 [accessed 08.05.14].

ONS (2015) 'Families and households, 2014', Table 1, http://www.ons.gov.uk/ons/publications/re-referencetables.html?edition=tcm\%3A77-383612 [accessed 24.02.15].

Osborne, G. (2012) 'Autumn statement 2012: Chancellor's statement', 5 December, https://www.gov.uk/government/speeches/autumn-statement-2012-chancellorsstatement [accessed 08.04.15].

Pareliussen, J. K. (2013) 'Work incentives and Universal Credit: reform of the benefit system in the United Kingdom', OECD Economics Department Working Paper No. 1033, Paris: Economics Department, Organization for Economic Cooperation and Development, http://www.oecd.org/officialdocuments/publicdisplaydocumentpdf/?cote=ECO/ $\underline{\mathrm{WKP}(2013) 25 \& \text { docLanguage }=\mathrm{En}}$ [accessed 01.04.15].

Rafferty, A. and Wiggan, J. (2011) 'Choice and welfare reform: lone parents' decision making around paid work and family life', Journal of Social Policy, 40, 2, 27593.

Reed, H., Elson, D. and Himmelweit, S. (2013) 'An adequate standard of living: a child rights based quantitative analysis of budgetary decisions 2010-13', London: Office of the Children's Commissioner, http://socialwelfare.bl.uk/subjectareas/services-client-groups/children-young- 
people/childrenscommissioner/151182An_adequate_standard_of_living-

_CRIA_supporting_report[1].pdf [accessed 01.04.15].

Rees, J., Whitworth, A. and Carter, E. (2014) 'Support for all in the UK Work Programme? Differential payments, same old problem', Social Policy \& Administration, 48, 2, 221-39.

Slater, T. (2012) 'The myth of "broken Britain": welfare reform and the production of ignorance', Antipode, 46, 4, 948-69.

Stewart, K. and Obolenskaya, P. (2015) 'The Coalition's record on the under fives: policy, spending and outcomes 2010-2015', Social Policy in a Cold Climate Working Paper No. 12, London: Centre for Analysis of Social Exclusion, London School of $\quad$ Economics, $\quad$ http://www.trustforlondon.org.uk/wpcontent/uploads/2015/01/SWP12.pdf [accessed 01.04.15].

Tinsley, M. (2014) 'Parenting alone: work and welfare in single parent households', London: Policy Exchange, http://www.policyexchange.org.uk/images/publications/parenting\%20alone.pdf [accessed 01.04.15].

Waldfogel, J. (2011) Britain's war on poverty, New York: Russell Sage Foundation.

Whitworth, A. (2013) 'Tailor-made? Single parents' experiences of employment support from Jobcentre Plus and the Work Programme', London: Gingerbread, http://www.gingerbread.org.uk/uploads/media/17/8158.pdf [accessed 23.02.15].

Whitworth, A. and Griggs, J. (2013) 'Lone parents and welfare-to-work conditionality: necessary, just, effective?', Ethics and Social Welfare, 7, 2, 124-40.

Wiggan, J. (2005) 'Employment and budgeting decisions of low-income working families over a period of welfare reform', PhD thesis, Nottingham: University of Nottingham. 
Williams, F. (2004) Rethinking families, London: Calouste Gulbenkian Foundation.

Wintour, P. (2013) 'Ed Miliband's proposals at a glance', The Guardian, 22 September. 
Appendix 1. Example Universal Credit calculation for Katherine assuming she works 35 hours a week at minimum wage $(£ 6.50$ per hour)

Table A1. Example calculation of Katherine's weekly Universal Credit award when working 35 hours at minimum wage

Steps for calculating Universal
Credit

Outcome

Maximum award

Standard allowance

$£ 73.34$

Child element: first child

$£ 63.94$

Child element: second child $\quad £ 53.46$

Housing element

$£ 92.01$

Childcare element

$85 \% \times £ 59.59=£ 50.65$

Total maximum award

$£ 333.40$

Income

Total gross earnings

$35 \times £ 6.50=£ 227.50$

Earnings after in work taxes

$£ 213.96$ 
Less earnings disregard

Total applicable income

Final award

$65 \%$ of applicable income

Total weekly award
$£ 213.96-£ 60.69=£ 153.27$

$£ 153.27$

$65 \% \times £ 153.27=£ 99.63$

$£ 99.63$ 
Sources:

https://www.gov.uk/government/uploads/system/uploads/attac hment_data/file/382867/proposed_benefit_and_pension_rates _2015_to_2016.pdf; own calculations. 


\title{
Appendix 2. Details of the assumptions made in the simulations
}

Table A2. Details of the assumptions made in the simulations

\author{
Assumption Details and sources \\ Inflation $\quad$ For all uprating between April 2011 and April 2013: \\ https://www.gov.uk/government/uploads/system/uploads/attac \\ hment_data/file/293312/abstract-of-statistics-2013.pdf (Table \\ $1)$. \\ Retail Prices Index, Rossi index and Average Weekly Earnings \\ index for uprating in April 2014: \\ http://www.parliament.uk/business/publications/research/briefi \\ ng-papers/SN06774/2014-benefit-uprating.
}

Office for Budget Responsibility forecast of Consumer Prices Index, Retail Prices Index and Rossi index for uprating in April 2015: http://budgetresponsibility.org.uk/economic-fiscaloutlook-march-2014/ (Economic and fiscal outlook supplementary economy tables, Table 1.7).

Forecast Average Weekly Earnings index for uprating in April 2015, based on latest available data (percentage annual change in the three-month average to April 2014): http://www.ons.gov.uk/ons/publications/re-referencetables.html?edition=tcm\%3A77-311468 (Table EARN01). 
Earnings $\quad$ Minimum wage for April 2015:

https://www.gov.uk/government/news/one-million-set-tobenefit-from-national-minimum-wage-rise-to-650.

Median hourly wage for all female employees in 2014 increased by the annual percentage change from previous year $(0.5$ per cent) to bring it up to 2015-6 prices:

http://www.ons.gov.uk/ons/publications/re-referencetables.html?edition=tcm\%3A77-337425/re-referencetables.html?edition=tcm\%3A77-328216 (Table 1.5a).

Childcare Term-time costs are average cost of a child-minder for latest costs available year of data increased by average change from previous year; school holiday costs are average cost of a school holiday club for latest available year of data increased by average change from previous year. The data are available from: http://www.familyandchildcaretrust.org/annual-holidaychildcare-costs-surveys.

Rent Average rent for Private Registered Providers of social housing for 2013 increased by annual change since 1997: https://www.gov.uk/government/statistical-data-sets/livetables-on-rents-lettings-and-tenancies (Table 704).

Council Tax Average Council Tax Band D (England only) as of 2014 increased by annual percentage change from previous year: https://www.gov.uk/government/uploads/system/uploads/attac 
hment_data/file/335851/Council_Tax_Levels_set_by_Local_A uthorities__Revised_August_2014.pdf.

Income Tax Previous system: 2010-1 rates and the 2010-1 personal allowance uprated to 2015-6 prices in line with the Retail Prices Index with rounding up to the nearest $£ 10$ : http://webarchive.nationalarchives.gov.uk/20101124143949/ht tp://www.hmrc.gov.uk/rates/it.htm.

Coalition's system: current rates and personal allowance announced for 2015-6:

https://www.gov.uk/government/uploads/system/uploads/attac hment_data/file/293759/37630_Budget_2014_Web_Accessibl e.pdf.

National Previous system: 2010-1 rates and the 2010-1 primary threshold Insurance uprated to 2015-6 prices in line with the Retail Prices Index with rounding to the nearest pound: http://webarchive.nationalarchives.gov.uk/20100202100434/di rect.gov.uk/en/nl1/newsroom/prebudgetreport2009/dg_183037

Coalition's system: current rates and the $2014-5$ primary threshold uprated to $2015-6$ prices in line with by the Consumer Prices Index with rounding to the nearest pound: http://www.hmrc.gov.uk/rates/nic.htm. 
Jobseeker's 2010-1 rates uprated to 2015-6 prices in line with the Rossi

Allowance index with rounding to the nearest 5 pence:

http://www.ifs.org.uk/tools_and_resources/fiscal_facts.

$£ 20$ disregard (frozen since 2001).

Tax credits 2010-1 rates uprated to 2015-6 prices in line with the Retail

Prices Index with rounding to the nearest $£ 5$, except for the family and child allowances in Child Tax Credit: 2010-1 family allowance is assumed (frozen since 2003); 2010-1 child allowance uprated by the Average Weekly Earnings index. Same percentage of childcare costs, earnings disregard and taper rates as of 2010-1 since these elements rarely changed: http://www.ifs.org.uk/tools_and_resources/fiscal_facts.

Council Tax 2010-1 lone parent allowance uprated to 2015-6 prices in line Benefit and with the Rossi index with rounding to the nearest 5 pence. Housing Child allowance is the sum of the projected Child Tax Credit Benefit child element and projected Child Benefit rate for subsequent children under the old system. Family premium is the sum of the projected Child Tax Credit family element and projected Child Benefit rate for the eldest child minus the rate for subsequent children under the old system. Additional earnings disregard for working 16 hours uprated to 2015-6 prices in line with the Retail Prices Index with rounding to the nearest 5 
pence:

www.rightsnet.org.uk/pdfs/HBCTB_Circular_A2_2010.doc.

Same lone parent disregard as of 2010-1 (frozen since 1990): https://www.gov.uk/government/uploads/system/uploads/attac hment_data/file/236962/hbgm-bw2-assessment-of-income.pdf.

Child Old system: 2010-1 rates uprated to 2015-6 prices in line with Benefit the Retail Prices Index with rounding to the nearest 5 pence: http://www.ifs.org.uk/tools_and_resources/fiscal_facts.

Coalition's system: current rates increased by one per cent and rounded to the nearest 5 pence as announced in the 2012 Autumn Statement: https://www.gov.uk/child-benefit-rates; https://www.gov.uk/government/publications/autumnstatement-2012-documents.

Universal Information on how Universal Credit is calculated:

Credit http://www.legislation.gov.uk/ukdsi/2013/9780111531938/bod $\mathrm{y}$; also see the following worked example: https://www.gov.uk/government/uploads/system/uploads/attac hment_data/file/288769/foi-5950-13.pdf.

Current rates uprated by one per cent and rounded to the nearest penny as announced in the 2012 Autumn Statement: https://www.gov.uk/government/uploads/system/uploads/attac 
hment_data/file/275291/Benefit_and_Pension_rates_201415.pdf.

85 per cent childcare subsidy.

Council Tax Same allowances as for Universal Credit. Maximum Council Reduction Tax eligibility is 91.5 per cent of Council Tax bill, as the nationwide median reduction in maximum support across all English councils under the Coalition is 8.5 per cent (author's calculations using https://docs.google.com/spreadsheet/ccc?key=0AkvoW4n_rB wYdG5DRGNsX3JnNTFsdlFCbXg1ZERRbXc\&usp=sharing\# gid=0). 